in vivo $31: 511-525(2017)$

doi:10.21873/invivo. 11090

Review

\title{
Mitochondrial Membrane Dynamics and Inherited Optic Neuropathies
}

\author{
ELENI BAGLI ${ }^{1,2}$, ANASTASIA K. ZIKOU ${ }^{3}$, NIKI AGNANTIS ${ }^{4}$ and GEORGIOS KITSOS ${ }^{2}$ \\ ${ }^{1}$ Institute of Molecular Biology and Biotechnology-FORTH, Division of Biomedical Research, Ioannina, Greece; \\ Departments of ${ }^{2}$ Ophthalmology, ${ }^{3}$ Clinical Radiology, and ${ }^{4}$ Pathology, University of Ioannina, Ioannina, Greece
}

\begin{abstract}
Inherited optic neuropathies are a genetically diverse group of disorders mainly characterized by visual loss and optic atrophy. Since the first recognition of Leber's hereditary optic neuropathy, several genetic defects altering primary mitochondrial respiration have been proposed to contribute to the development of syndromic and nonsyndromic optic neuropathies. Moreover, the genomics and imaging revolution in the past decade has increased diagnostic efficiency and accuracy, allowing recognition of a link between mitochondrial dynamics machinery and a broad range of inherited neurodegenerative diseases involving the optic nerve. Mutations of novel genes modifying mainly the balance between mitochondrial fusion and fission have been shown to lead to overlapping clinical phenotypes ranging from isolated optic atrophy to severe, sometimes lethal multisystem disorders, and are reviewed herein. Given the particular vulnerability of retinal ganglion cells to mitochondrial dysfunction, the accessibility of the eye as a part of the central nervous system and improvements in technical imaging concerning assessment of the retinal nerve fiber layer, optic nerve evaluation becomes critical - even in asymptomatic patients - for correct diagnosis, understanding and early treatment of these complex and enigmatic clinical entities.
\end{abstract}

This article is freely accessible online.

Correspondence to: Niki Agnantis, Department of Pathology, University of Ioannina, Stavros Niarchos Avenue, 45500 Ioannina, Greece. Tel +30 2651007792, Fax: +302651007792, e-mail: agnantin@gmail.com and Georgios Kitsos, Department of Ophthalmology, University of Ioannina, Stavros Niarchos Avenue, 45500 Ioannina, Greece. Tel: +30 2651099657, Fax: +30 2651007077, e-mail: gkitsos@cc.uoi.gr

Key Words: Mitochondrial membrane dynamics, optic neuropathy, OPA1, MFN, DRP1, AFG3L2, SPG7, YME1L, MFF, OPA3, SLC25A46, ATAD3A, review.
Mitochondria represent a tubular and branched membrane system playing a fundamental role in several cellular processes required for the development and maintenance of an organism, such as metabolism, apoptosis, ion buffering and autophagy (1-3). They reveal a high degree of interconnectivity and plasticity, mainly dictated by metabolic status and developmental stage (4) and, therefore, a constant state of mitochondrial network flux is fundamental. This dynamic state is achieved through mitochondrial dynamics, a complex machinery of highly conserved mechanisms, including mitochondrial fusion, fission, transport, interorganellar communication and mitochondrial quality control (i.e. mitophagy), tuned to a variety of signals and stimuli (5-7), and well-orchestrated by specific intracellular proteins.

The morphology and intracellular distribution of mitochondria vary significantly between tissues and cell types, being enriched in areas of increased metabolic demand, such as neurons, especially the presynaptic and postsynaptic terminals (8). Accordingly, it is not surprising that the pathogenic mechanism of various neurodegenerative diseases is established through an underlying deficiency of mitochondrial energy metabolism (9). However, in recent years it has been shown that impairment of mitochondrial dynamics also leads to synaptic dysfunction, dendritic and axonal degeneration and consequently to neurodegeneration $(10,11)$. In this respect, restoration of mitochondrial function has become, for some time now, the priority target of novel neuroprotective strategies (12).

Mitochondrial membrane dynamics, and more specifically fission and fusion, are indispensable for mitochondrial distribution and homeostasis. Fusion, the physical merger of two neighboring mitochondria, is necessary for the functional complementation between individual mitochondria via intermixing and exchanging proteins, respiratory complexes and mitochondrial DNA (mtDNA) nucleoids $(13,14)$. It is continuously counterbalanced by fission, a process necessary for the appropriate distribution of mitochondria in dividing cells, as well as their transportation and distribution throughout 
the length of neurons (15). Furthermore, fission is essential for mitophagy, a quality-control mechanism that enables the elimination of damaged mitochondria by autophagosomes, and for the distribution of mtDNA nucleoids (16).

The association and balance between mitochondrial fusion and fission, and selective mitophagy, are intricate and tightly coordinated $(17,18)$. By altering the delicate balance between opposing fusional and fissional forces and modifying the architecture of the organelle itself, in particular the cristae, which house the protein complexes of the oxidative phosphorylation system, the cell has been shown to regulate cell proliferation (19) and energy metabolism (4, 20, 21).

Four large guanosine-5' -triphosphate hydrolases (GTPases), members of the dynamin superfamily located in the cytosol or inner (IMM) and outer (OMM) mitochondrial membranes, mediate mitochondrial fusion and fission. Specifically, optic atrophy 1 (OPA1), and mitofusins 1 and 2 (MFN1 and -2) mediate mitochondrial fusion (22), while dynamin-related protein 1 (DRP1) is essential for fission (23).

Mitochondrial fusion is necessarily a multistep process, since at least two distinct membrane fusion events occur. The OMM and IMM, which delineate a mitochondrion, merge with the corresponding membranes on another mitochondrion. These events result in mixing of the membranes, the intermembrane space (IMS), and the matrix. MFN1 and MFN2 are highly conserved and have been identified as mediators of OMM fusion (24). OPA1 on the other hand is involved in IMM fusion and morphology of mitochondrial cristae (25-27). It is synthesized within the cytoplasm as a pre-protein and once transported into the mitochondria undergoes proteolytic cleavage to generate long (L-OPA1) and short (S-OPA1) isoforms of OPA1 (28). This OPA1 processing is reported to be regulated by several mitochondrial proteases including presenilin-associated rhomboid-like (PARL) (25), mitochondrial ATPases associated with diverse cellular activities (m-AAA) proteases (paraplegin and ATPase family gene 3-like protein 2AFG3L2) (29), the mitochondrial inner membrane AAA (iAAA) protease yeast mitochondrial escape (YME1)-like 1 ATPase (YME1L) and the membrane-bound metallopeptidase with activities overlapping with the m-AAA protease (OMA1) (30). Mutations in $M F N 2$ and $O P A 1$ gene were initially reported as being responsible for the rare neurodegenerative diseases Charcot-Marie-Tooth subtype 2A (CMT2A) and autosomal dominant optic atrophy (DOA), respectively $(31,32)$.

DRP1, the key player in fission, localizes primarily to the cytosol, but upon activation of mitochondrial fission, it is oligomerized and recruited by OMM-localized receptors, mainly mitochondrial fission factor (MFF) $(18,33,34)$, mitochondrial division 49/51 (MiD49/51) (33), and less apparently mitochondrial fission 1 (FIS1) $(18,33)$, to the OMM, where it forms high-molecular-weight protein complexes marking active or prospective fission sites (23). Mitochondrial recruitment, assembly, activity and stability of DRP1 are regulated by several post-translational modifications $(35,36)$.

The recognition of all the implicated molecular players and their exact role in fission/fusion has not been elucidated yet and remains an area of intense investigation. Accumulative evidence suggests that the role of mitochondrial dynamic proteins regarding fusion and fission machinery is not that distinguishable. Mitochondrial fusion proteins, such as OPA1, can regulate mitochondrial fission (30), and DRP1-dependent changes in mitochondrial morphology, on the other hand, might control MFNs and OPA1 (37). Furthermore, recent studies have pinpointed the importance of epigenetic and posttranslational modifications of the known key players DRP1, MFNs and OPA1 in the regulation of their function $(25,35$, 36, 38, 39). Remarkably, mutations in several of these regulatory proteins (usually involved in protein processing) have been identified lately as causal gene products of syndromic or nonsyndromic inherited optic neuropathies.

Inherited optic neuropathies are a clinically and genetically heterogenous group of disorders, characterized by typically bilateral, symmetrical, irreversible reduced visual acuity, color vision deficits, visual field defects and the clinical appearance of optic atrophy (40). The clinical spectrum usually varies even between the members of the same family and, in some cases, individuals develop additional neurological complications indicating a greater vulnerability of the central nervous system (CNS) in susceptible mutation carriers (41). Therefore, besides isolated optic neuropathies, optic atrophy is recognized as a prominent feature in many neurodegenerative diseases caused by primary mitochondrial dysfunction. However, because of the heterogeneity and the highly variable phenotypes of these disorders, their diagnosis becomes a challenging task. Moreover genotype-phenotype correlations are usually highly speculative, probably because of tissue-specific expression of different isoforms of the affected protein, secondary unrecognized genetic factors and insufficient knowledge concerning the multi-factorial process of mitochondrial dynamics. However, during the last few years there has been an expansion of data concerning the phenotypic and genotypic spectrum of these disorders because of improved diagnostic imaging [magnetic resonance imaging (MRI), optical coherence tomography (OCT)] and molecular technology (DNA sequencing, transgenic animal models etc.). As a result, a greater understanding of the complex molecular mechanisms underpinning this broad range of neurodegenerative diseases is expected in the near future.

In light of this new evidence, the role of the main molecular players of mitochondrial fusion/fission machinery in the pathogenesis of inherited optic neuropathies is discussed in this review. Particular emphasis is placed on novel mitochondrial dynamic proteins, whose mutations were recently identified as accounting for the development of clinical entities involving the optic nerve only or in association with extraocular manifestations. 


\section{Mitochondrial Dynamic Proteins Related to the Pathogenesis of Optic Neuropathy}

OPA1. The OPA1 gene, encodes a 960-amino-acid, dynaminlike mitochondrial GTPase. OPA1 open reading frame (ORF) comprises of 30 exons and 8 transcript variants (42), whose expression is tissue-specific in humans (43-45), and which arise from alternative splicing of three exons. OPA1 is ubiquitously expressed, localized to the IMS and is firmly anchored to the IMM via an $\mathrm{N}$-terminal transmembrane segment containing a mitochondrial targeting sequence (MTS) $(38,46)$. It also displays a GTPase domain, a dynamin central region and a coiled-coil $\mathrm{C}$-terminal domain that correspond to the dynamin GTPase effector domain (GED), involved in oligomerization of this protein into cylindrical tubular structures and catalytic activation $(44,47)$. The OPA1 protein is synthesized as a precursor that undergoes complex proteolytic processing within the mitochondria (38). Matrix metalloproteases first remove the IMS during mitochondrial import to give rise to IM-anchored L-OPA1, $(38,46)$, which can undergo further proteolytic cleavage leading to the production of S-OPA1 (28) (46). S-OPA1 interacts with uncleaved forms of L-OPA1 at crista junctions and with subunits of the mitochondrial contact site and cristae organizing system (MICOS), which is involved in the maintenance of crista structure (48-50).

L-OPA1 is responsible for mitochondrial fusion, while $\mathrm{S}$ OPA1 was shown to be involved in IMM fission, when accumulated $(30,51)$, indicating a highly regulated, dual role of OPA1 in fusion and fission (30). The levels of L- and S-OPA1 can vary dramatically across tissues (30) and due to various stress conditions. A drop in mitochondrial membrane potential and induction of apoptosis, for instance, may induce massive processing of L-OPA1 to S-OPA1 $(28,51)$. The balance between the different isoforms of OPA1, dictated by the posttranslational maturational steps of OPA1, plays a fundamental role in mitochondrial morphology, the regulation of mitochondrial fusion and fission $(25,28,51)$, the organization of cristae, the maintenance of membrane potential, calcium clearance and the assembly of respiratory chain supercomplexes for achieving maximal respiratory efficiency $(26,27,52,53)$. It was recently shown that OPA1 senses energy substrates in order to regulate crista structure, in a manner dependent on solute carrier 25A (SLC25A) protein (54), while proteolytic activation of OPA1 is sufficient to stimulate IMM fusion in a process that is sensitive to oxidative phosphorylation (55). Moreover, a direct role of OPA1 in mtDNA maintenance has been attributed to a small IM-anchored OPA1-derived peptide (52) and loss of mtDNA was recently observed upon loss or down-regulation of OPA1 (52). Finally, OPA1 was reported to have independent anti-apoptotic activity mediated by particular OPA 1 splice variants (44), oligomerized to complexes that control apoptotic crista remodeling (48).
OPAl mutations are the most frequently found in patients with non-syndromic DOA, and to date, more than 250 mutations of this gene have been identified (32). Isolated DOA is characterized by a homogeneous phenotype including progressive, bilateral visual impairment occurring during the first two decades of life, temporal optic disc pallor, loss of the central visual field and color vision defect $(56,57)$. This disease affects primarily the retinal ganglion cells (RGCs), whose axons form the optic nerve and the estimated prevalence is $1: 10,000$ to $1: 50,000$. OPA1 mutations were found in about $60-80 \%$ of patients with DOA, with incomplete penetrance in $43-100 \%$ of the cases (56). Cases with de novo mutation, sporadic cases, and cases with unknown familial history, account together for $50 \%$ of all patients (56). The visual impairment is irreversible, usually moderate, but highly variable between and within families, ranging from asymptomatic state to blindness. Up to $20 \%$ of OPA1-related disorders are syndromic (58) (called DOA-plus syndrome). The extraocular involvement includes sensorineural deafness, ataxia, myopathy, chronic progressive external ophthalmoplegia and peripheral neuropathy, usually presented after optic neuropathy during young adulthood. Visual acuity and optic nerve damage is typically worse in DOA-plus patients compared to ones with isolated optic neuropathy (59) and deafness seems to be the most common extraocular symptom just after optic neuropathy. Brain MRI also discloses various cerebral abnormalities, including lactate peak, as well as cerebellar and cortical atrophy, present even in nonsyndromic cases (60). Finally, DOA-plus form presented in young adulthood has been distinguished further into typical DOA-plus and to severe early-onset Behr-like syndromes (61).

Since the spectrum of OPA1-related disorders is highly variable regarding the age of onset, the severity of visual loss, and the number, type and severity of extraocular symptoms, it is still unclear if these various DOA phenotypes represent different aspects of one clinical condition or constitute distinct clinical entities (61). Interestingly, a recent report suggests that OPAl mutations may also be implicated in systemic conditions, including spastic paraplegia, multiple sclerosis, Parkinsonism or dementia (61). However, despite this large clinical heterogeneity, most dysfunctions concern the central, peripheral and autonomous nervous system.

OPAl mutations are spread along the coding sequence of the gene but most cluster in the GTPase domain and in the dynamin central region. Single base-pair substitutions represent the most common mutational subtype, followed by deletions, and insertions $(47,62)$. In some cases, there are two (different) missense mutations on different alleles which, although recessive, lead to a stronger phenotype compared to either of the single mutations $(61,63)$. Among the few recurrent variants, some have been frequently reported, such as a deletion in the GED at the C-terminus (61). Since OPA1 oligomerizes (48), mutations in the GED domain of one allele can complement mutations in the GTPase domain of another 
allele (64). Genomic rearrangements in $O P A 1$ gene, as well as deletion of the entire one copy or part of the OPAl gene have been reported $(63,65,66)$, indicating haploinsufficiency as the main pathogenic mechanism. Overall, the majority of OPAl mutations result in premature termination codons and unstable truncated mRNAs, which are degraded by protective surveillance mechanisms operating via nonsense-mediated mRNA decay $(63,67,68)$, providing further evidence for haploinsufficiency. Missense OPAl mutations affecting the catalytic GTPase domain in patients with DOA, on the other hand, are more likely to exert a dominant-negative effect (47, $58,69,70)$ and these patients have a two-to three-fold increased risk of developing syndromic DOA compared to those with truncating mutation $(58,61,71)$. Although these syndromic DOA variants are characterized by significant phenotypic variability, a worse visual prognosis as well as thinner retinal nerve fiber layer evaluated by OCT (72) suggest a deleterious gain-of-function effect of these mutations. The different mutations in OPAl are usually not correlated with the severity of the disease (73). In this respect, mtDNA instability, due to defective mitochondrial dynamics caused by a dysfunction of the $O P A 1$ gene, has been identified in DOA-plus patients $(70,74)$ and could be responsible for the multisystem phenotype through direct functional consequence on the respiratory chain capacity $(61,70,74,75)$. It could also explain the clinical overlap between syndromic DOA and other related to mtDNA mutation-associated disorders. However, mtDNA deletions are also present in patients with isolated DOA (76). Secondary nuclear genes are also suspected to control the severity of the disease in nonsyndromic patients $(61,77)$.

Impairments of mitochondrial morphology (78) and functions, including increased autophagy or apoptosis (44), generation of reactive oxygen species (75) and impaired oxidative phosphorylation $(4,68,74,75)$, are evident in cells derived from affected patients. Although defects in the respiratory chain are less consistent in reports $(75,79)$, the widespread deleterious consequences of OPAl mutations on RGCs, as well as other neuronal cell types and skeletal muscle (61), are well documented.

m-AAA proteases: spastic paraplegia 7 (SPG7) and (AFG3L2). SPG7 (paraplegin) and its close homolog AFG3L2 contain a M41 metallopeptidase domain and an ATPase domain characteristic of the AAA family of ATPases ( $m$-AAA proteases) (80). They form a hetero-oligomeric proteolytic complex at the IMM, responsible for the proteolytic cleavage of mitochondrial ribosomal protein L32 (MRLP32) and OPA1 (29). As a result, they regulate the equilibrium between profusion and pro-fission isoforms of OPA1 (81). Moreover, AFG3L2 and SPG7 homo and hetero-polymeric hexameric functional complexes (82) play essential roles in protein quality control within mitochondria and have broad functional targets including control of ribosome and respiratory chain subunits assembly $(83,84)$ and degradation of misfolded proteins $(85)$.

$S P G 7$. Paraplegin is the product of the SPG7 gene. Recent literature suggests that SPG7 also plays an essential role in the regulation of the mitochondrial permeability transition pore (86). Impaired axonal transport, ultrastructural mitochondrial abnormalities, including aberrant cristae, as well as hyperfragmentation of the mitochondrial network, have been demonstrated in paraplegin-deficient mice (87), features similar to those of cells isolated from OPA1-deficient patients.

Mutations of the SPG7 gene are responsible for both the autosomal recessive form of hereditary spastic paraplegia (HSP) (88) involving the optic nerve and autosomal dominant non-syndromic optic neuropathy (89).

HSPs are a group of similar neurodegenerative disorders with a clinical presentation of weakness and spasticity in the lower limbs (90). Mutations in SPG7 were initially reported in three families, two with isolated spasticity and one with a complex phenotype (91), characterized by age of onset ranging from 10 to 45 years (92-95), cerebellar involvement with/without mild cerebellar atrophy observed on MRI scans $(91,93,94,96,97)$, optic neuropathy $(91,92)$, ptosis $(94,95)$ and supranuclear palsy (94). Optic neuropathy usually presents as mild or subclinical visual impairment, revealed only by OCT. SPG7-related DOA, on the other hand, is characterized by progressive visual loss starting the first decade of life, with final visual acuity of 1/10-3/10 in the second decade (89).

The mutational spectrum responsible for HSP ranges from missense and nonsense mutations to large intragenic SPG7 deletions (90). Among them, strong evidence has been provided regarding the pathogenic role of p.Ala510Val variant, which leads to disturbed proteolytic function of the heterooligomeric m-AAA protease $(92,93,97-99)$. On the other hand, Asp411Ala mutation, the first mutation segregating with isolated autosomal dominant optic neuropathy, is located in the AAA domain of the protein, downstream of the Walker B motif (which with the upstream Walker A motif are implicated in the fixation and hydrolysis of ATP) and causes impaired proteolytic activity (89).

Because paraplegin is closely related to AFG3L2, is incapable of self-assembling into homo-oligomers and requires $A F G 3 L 2$ for its function, it has been suggested that variants in $A F G 3 L 2$ might also act as genetic modifiers contributing to the clinical heterogeneity and the variable severity of SPG7-related diseases.

$A F G 3 L 2$. Heterozygous missense mutations in the $A F G 3 L 2$ gene have been shown to be responsible for autosomaldominant spinocerebellar ataxia type 28 , characterized by onset in young adulthood, slowly progressive gait and limb ataxia, increased reflexes, dysarthria and ophthalmoparesis (89, 100, 101). Patients harbouring homozygous AFG3L2 
mutations present with a more severe phenotype including dystonia, oculomotor apraxia, and progressive myoclonic epilepsy (102), but not optic neuropathy.

However, a novel mutation p.Arg468Cysc in a highly conserved arginine-finger motif in the AAA domain of AFG3L2 was reported recently to account for the development of DOA presenting as bilateral, symmetrical visual loss starting in infancy accompanied by mild mental retardation without signs of cerebellar impairment (103).

$i$-AAA protease YME1L. YME1L1 belongs to the AAA family of ATPases and it is a nuclear genome-encoded ATPdependent metalloprotease. YME1L1 is embedded in the IMM, while its protease domain faces the IMS ( $i$-AAA protease) (104-106). YME1L1 contains a MTS, which is cleaved-off by mitochondrial processing peptidase once it is imported into mitochondria (107). The mature protein then assembles into a homo-oligomeric complex within the IM $(104,108)$. YME1L1 degrades both IMS and IM proteins, such as lipid transfer proteins (109), components of protein translocases of the IM $(110,111)$, and OPA1 at S2 site (30, $111,112)$. Depletion of YME1L1 was shown to cause increased mitochondrial fission and mitochondrial network fragmentation through acceleration of OMA1-dependent LOPA1 cleavage, which leads to S-OPA1 accumulation (30, 113), or through a mechanism involving DRP1 and MFF (114). Finally, loss of YME1L1 perturbs crista morphogenesis, and renders cells susceptible to apoptosis (115).

YME1L1 mutations were recently recognized as accounting for infantile-onset developmental delay, muscle weakness, ataxia, and optic nerve atrophy. Homozygous missense mutation $(\mathrm{c} .616 \mathrm{C}<\mathrm{T})$ located in a highly conserved region in the mitochondrial pre-sequence of YME1L1 leads to inhibition of its cleavage by the mitochondrial processing peptidase and the subsequent rapid degradation of YME1L1 precursor protein. The abnormal processing of OPA1, due to impaired YME1L1 function, was shown to cause proliferation defect and mitochondrial network fragmentation (116) and seems to be the main molecular mechanism underlying the pathogenesis of this YME1L1 mutation.

MFN1 and 2. MFN 1 and -2 are two homolog GTP-binding proteins of the dynamin-superfamily involved in OMM fusion (117) and expressed ubiquitously but differently in various tissues $(117,118)$. They share an $N$-terminal GTPase domain followed by a first coiled-coiled heptad repeat region (HR1), two adjacent small transmembrane domains and a $C$-terminal second coiled-coiled heptad repeat region (HR2). MFN2, but not MFN1 also possesses an $N$-terminal RAS-binding domain (119). The $N$-terminal and C-terminal domains extend perpendicularly into the cytosol, while the hydrophobic domain spans the OMM (117), resembling an unfolded mitofusin conformation optimal for mitochondrial tethering and therefore permissive for fusion $(120,121)$. However, it seems that conformational plasticity exists and mitofusins adopt either a fusion-constrained or fusion-permissive molecular conformation directed by specific intramolecular binding interactions through HR1 and HR2 domains $(120,122)$. MFN1/2 form homo- and hetero-oligomers on the OMM and are required for an elongated mitochondrial network (24). MFN2 plays a fundamental role in mitochondrial dynamics, including mitochondrial transport, mitophagy and communication with other organelles $(11,123)$, as well as in cellular bioeneretics. Specifically, it coordinates mitochondrial fusion by working in close tandem with its fellow fusogenic protein, OPA1 (124), and it is involved in mitochondrial biogenesis $(21,125)$ by regulating the expression of nuclear-encoded respiratory chain subunits (126). It is also important for tethering mitochondria to the endoplasmic reticulum (ER) (127) and modulating some functions of the ER $(128,129)$. Furthermore, it is implicated in apoptotic cell death and OMM permeability, oxidative phosphorylation (126) and microtubule-related mitochondrial transport in axons via interaction with Miro-proteins $(130,131)$. Therefore, it is not a surprise that deletion of MFN2 is embryonically lethal and alterations of its functions have been associated with a number of different pathological conditions, ranging from neurodegeneration to impaired glucose homeostasis $(11,129)$. Interestingly, no disease has been associated with mutations of MFN1.

MFN2 mutations account for $20 \%$ of Charcot-Marie-Tooth disease type 2 (CMT2) cases, making this the most prevalent axonal form of CMT $(31,132)$. CMT2A is a neurological disorder characterized by complex phenotypes, including not only neuropathy-related features but also systemic impairment of the CNS (11). Both autosomal dominant and autosomal recessive inheritance of these mutations, as well as sporadic new mutations have been described (133). Furthermore, truncation mutations in MFN2 have been shown to be responsible for hereditary motor sensory neuropathy type VI (HSMN VI), a rare early-onset axonal type of CMT associated with bilateral sub-acute, sometimes improved spontaneously, or acute optic neuropathy (11, 31, 134-136). Although symptoms and disease severity are heterogeneous, the frequency of MFN2 mutations was shown to be significantly higher among severely affected patients with CMT2A (137, 138). MFN2 mutations might also be found in all subtypes of CMT (139). Moreover, MFN2 mutations are linked to a spectrum of clinical manifestations wider than CMT2 neuropathy alone. Indeed, a phenotype resembling the DOAplus phenotype, characterized by early-onset optic atrophy, axonal neuropathy and mitochondrial myopathy, has been associated with a novel MFN2 missense mutation (c.629A > T, p.D210V) accompanied by multiple mtDNA deletions (140). Furthermore MFN2-related disorders may even mimic multiple sclerosis, when presenting with optic atrophy, brain lesions on MRI and mild or unrecognized neuropathy (141). 
Most MFN2 mutations in CMT2A are missense and cluster within the GTPase and in the HR1 domains (31, 137, 138, 142, 143). A mutational hotspot region located immediately upstream of the GTPase domain has been recognized (31). Previous reports suggested that patients with compound heterozygosity have more severe neuropathy, and their phenotypes are consistent with an additive dominant negative effect of MFN2 mutations (144). Some mutations lead to a gain of function, since the mutated protein tends to aggregate in mitochondria, while other mutants result in loss of function. Since mitochondrial fusion is impaired $(31,145)$, the subsequent disequilibrium between fusion and fission processes may negatively affect cell function and serve as a potential mechanism of neurodegeneration (11). However, the pathogenicity of MFN2 mutations is suggested to rely also on other functions of the MFN2 protein, such as the interaction between mitochondria and the organelle transport machinery. Indeed recently, several studies using in vitro and in vivo models of CMT2A highlighted the relationship between impaired mitochondrial trafficking due to MFN2 mutations and axonal degeneration (11).

Particular MFN2 mutations have been associated with specific clinical features. In this way, visual impairment has been associated with missense or nonsense mutations and incomplete penetrance of visual loss has been linked to Q276R mutation (11). However it seems that a genotypephenotype correlation cannot be establish. The same mutation can be associated with both early- and late-onset disease, as well as different signs and symptoms, even among members of the same family (135), which is probably due to environmental or other factors that modulate genetics (11).

OPA3. OPA3 is composed of at least three exons that are alternatively spliced to produce two major transcripts: OPA3A and OPA3B, (146). Defects in OPA3 have been associated with both recessive and dominant optic neuropathy (147). Interestingly, mutations of $O P A 3, O P A 1$ and $S P G 7$ have all been shown to be responsible for non-syndromic DOA. 3Methylglutaconic aciduria type III (3-MGCA type III), also known as Costeff optic atrophy syndrome, is a neuroophthalmological syndrome caused by recessive mutations in the $O P A 3$ gene, most prevalent amongst individuals of IraqiJewish origin and typically characterized by early-onset bilateral optic atrophy, late development of a movement disorder (ataxia or extrapyramidal dysfunction) of variable severity beginning in the first or second decade of life, and increased urinary excretion of 3-methylglutaconic acid (148152). Autosomal dominant OPA3-related disease on the other hand is less common than the recessive form, with only a few families identified to date (147), but highly penetrant (153). It is characterized by optic neuropathy either isolated or more often associated with congenital/infantile lenticular opacity, hearing loss and neurological symptoms (147). It is a clinically heterogeneous disorder, indicating a complex molecular pathology. Some patients present with poor visual acuity and nystagmus from birth, while others experience a slowly progressive, symmetrical decrease in vision starting in the first two decades of life, or remain asymptomatic until later in life. The optic neuropathy is similar to that caused by OPAl mutations characterized by primary involvement of the papillomacular bundle (147). The phenotypic spectrum of autosomal dominant mutations in OPA3 was further expanded recently with the identification of a de novo mutation in exon 2 encoding OPA3 Leu79Val, which leads to an unusually severe phenotype including optic atrophy, cataracts, ataxia, and peripheral and autonomic neuropathy (154).

The functional and biological role of OPA3 is still unclear. The presence of a putative $N$-terminal MTS indicates its import into mitochondria (146). However the studies concerning OPA3 localization in the IMM or OMM are controversial $(146,155,156)$. The $N$ - and $C$-terminal regions are reported to be exposed to the IMS and cytoplasm, respectively. OPA3 seems to play a regulatory role in mitochondrial dynamics and more specifically in fission, since overexpression of $O P A 3$ significantly induced mitochondrial fragmentation. It is also referred to as sensitizing cells to apoptosis (156).

The three known 3-MGCA type III-related mutations are all assigned to exon 2 of $O P A 3 A$ (157) and its adjacent splice site (146, 149), while G93S and Q105E mutations lead to DOA associated with cataracts and extrapyramidal signs (158). Overexpression of a familial OPA3 mutant (G93S) induced mitochondrial fragmentation and spontaneous apoptosis, suggesting that OPA3 mutations may cause optic atrophy via a gain-of-function mechanism (156). Furthermore, a novel insertion, c.10_11insCGCCCG/p.V3_G4insAP, which is located in the mitochondrial presequence, results in decreased steady-state levels of the mutant protein compared with the native one and leads to DOA and hearing loss (153). A fragmented mitochondrial network and reduced mitochondrial mass was observed in cells isolated from individuals harboring this novel mutation (153).

SLC25A46. SLC25A46 belongs to the SLC25 family of mitochondrial carrier proteins responsible for the transfer of diverse substrates across the IMM (159). SLC25A46 is an ortholog of UGO1, a yeast outer membrane protein essential for mitochondrial membrane fusion (160-163). It is an integral OMM protein which has been shown to interact with the IMM remodeling protein mitofilin (164), OPA1 and MFN2 (165, 166). Moreover, the oligomerization of OPA 1 and the regulation of OPA1-dependent crista modulation, a cellular adaptation to metabolic demand, were shown to be dependent on SLC25A46-OPA1 interaction (54). SLC25A46 also interacts with components of the MICOS complex, which is indispensable for the maintenance of mitochondrial crista 
junctions (166-171). However, unlike UGO1, SLC25A46 acts as a pro-fission component in the regulation of mitochondrial dynamics $(160,165)$. Loss of SLC25A46 results in a hyperfused mitochondrial phenotype in human cells $(164,166$, 172) due to increased stability and oligomerization of MFN $1 / 2$ on mitochondria (166). A recent study showed that SLC25A46 plays an important role in the maintenance of architecture of mitochondrial cristae and mitochondrial lipid homeostasis by functioning upstream of the MICOS complex and by interacting with the $\mathrm{ER} /$ mitochondrial contact site complex, respectively $(173,174)$. However, further investigation is needed, since this mechanism of action was questioned by another study using a different cell system (166). Since SLC25A46 is involved in mitochondrial ultrastructure via interaction with a large number of proteins and formation of transient complexes, it probably acts as a coordinator of rapid changes needed in mitochondrial dynamics and crista morphology in response to changes of the microenvironment.

Recessive SLC25A46 mutations were recently identified in a syndrome named optic atrophy spectrum disorder that has since been designated hereditary motor and sensory neuropathy type VIB (HMSNVIB), which covers a broad clinical spectrum including early-onset optic atrophy, peripheral neuropathy and cerebellar degeneration, with variable age of onset and severity (164). In particular, SLC25A46 was identified as a new locus accounting for congenital pontocerebellar hypoplasia ( $\mathrm{PCH}$ ) a lethal condition considered as one extreme of HMSNVIB. The impact of SLC25A46 mutations on the variable phenotype of HMSNVIB seems to be dictated by the relative stability of the encoded protein (164). In agreement with that, destabilized and nonfunctional mutant SLC25A46 L341P correlates with the phenotype of lethal congenital $\mathrm{PCH}$ syndrome and a homozygous missense mutation in SLC25A46 (c.425C > T), also causing destabilization and loss of SLC25A46 function, was shown to account for the development of Leigh syndrome, an early-onset and fatal neurodegenerative disease associated with bilaterally symmetric lesions in the brainstem, basal ganglia, and spinal cord. Therefore, the regulation of SLC25A46 level seems to be fundamental for its function. In accordance with this, ubiquitin ligases were reported to contribute to the selective and rapid degradation of SLC25A46 L341p by the proteasome (166).

ATPase family AAA-domain containing protein $3 A$ (ATAD3A). ATAD3A is a nuclear-encoded protein, ubiquitously expressed in multicellular organisms. ATAD3A interacts simultaneously with both the IMM and OMM and it seems to be devoid of the function of mitochondrial $\mathrm{AAA}^{+}$protease, since it lacks a proteolytic domain. Monoallelic and biallelic variation involving both single-nucleotide variants and copy-number variants at the ATAD3A locus was recently recognized in seven families as leading to a primarily neurological disease characterized by global developmental delay, hypotonia, optic atrophy and axonal neuropathy (175).

The ATAD3 gene family in humans includes three paralogs (ATAD3A, ATAD3B, ATAD3C) $(176,177)$. ATAD3A has an $N$ terminal domain including two coiled-coil domains with high oligomerization probability that interacts with the OMM and a central transmembrane segment, which anchors the protein in the IMM and positions the $C$-terminal AAA(+) ATPase domain (Walker A and Walker B) in the matrix. ATAD3A interacts simultaneously with both mitochondrial membranes and therefore, it regulates mitochondrial dynamics at the interface between the IMM and OMM and is involved in several cell responses, such as cell growth, enhanced channeling of cholesterol for hormone-dependent steroidogenesis (178-180) and mitochondrial fission (178). It was also shown to play a role in mtDNA maintenance and replication (181), as well as cancer cell growth and metastasis (182). Loss of function of ATAD3A at contact sites between the OMM and IMM was shown to induce cell fission machinery (178). Since ATAD3A can co-immunoprecipitate with MFN2, OPA1 and DRP1, a possible role of ATAD3A in mitochondrial dynamics could be maintained through these interactions (178).

Defective ATP-binding ATAD3A mutations were shown to interfere with normal oligomer functions leading to fragmentation of mitochondria (178). Furthermore, the p.Arg528Trp variant was shown to act through a dominantnegative mechanism in fibroblasts isolated from affected individuals by generating small mitochondria that trigger mitophagy (175). On the other hand, the recessive copynumber variants lead to infantile lethality through loss of ATAD3A function.

DRP1. DRP1 is a dynamin-related GTPase essential for mitochondrial fission in mammalian cells. It is recruited to mitochondria via receptors, reversibly associate with the OMM and further assembles around mitochondrial tubules to form an oligomeric ring that constricts and divides the mitochondrion in a GTP-dependent process $(23,183,184)$. It contains four distinct domains: GTP-binding, middle, insert B, and GED (185). Mutation of DRP1 blocks mitochondrial fission, resulting in elongated mitochondrial networks due to unopposed mitochondrial fusion (23). This cellular defect causes developmental lethality in mice (186). Only a single case study of a patient with a DRPI mutation has been described (187). This patient was a newborn girl, who died at 37 days due to multisystem abnormalities, including small head circumference, hypotonia, few spontaneous movements, optic atrophy and poor feeding. The heterozygous mutation (A395D) in this patient located in the middle domain, important for selfassembly, suggests that this mutant dramatically disrupts higher-order assembly of DRP1 and thereby reduces assemblyinduced GTP hydrolysis in a dominant-negative mode of action 
(185). Analysis of the isolated fibroblasts showed elongated mitochondria and peroxisomes.

$M F F$. MFF is essential for fission of mitochondria and peroxisomes $(34,188)$. It is considered the major membrane DRP1 receptor and important regulator of organelle fission (33, 184, 189). Interestingly, MFF was shown to efficiently stimulate the GTPase activity of the brain-specific DRP1 isoform compared to ubiquitously expressed isoform and to mediate DRP1 recruitment to synaptic vesicles (189). As a result, when it is knocked-down, mitochondria become elongated (34) and the amount of DRP1 recruited to them is reduced. MFF is anchored in the OMM through its C-terminal transmembrane segment. The sequence of MFF indicates that it also interacts with other proteins and participate in protein complexes that mediate the fission pathway $(33,34)$.

A truncating mutation in MFF was first identified in a Saudi Arabian boy with delayed psychomotor development, spasticity, optic atrophy, and bilateral, increased signal intensities of the basal ganglia (190). Furthermore, recently three boys with similar overlapping phenotype were found to carry truncating mutations in MFF (191). The disease onset was in the first year of life, characterized by seizures, developmental delay and acquired microcephaly, followed in subsequent years by dysphagia, spasticity, optic neuropathy and peripheral neuropathy (191). Brain MRI showed Leighlike patterns, with bilateral changes of the basal ganglia and subthalamic nucleus, indicating impaired mitochondrial energy metabolism (191). However, the activiity of mitochondrial respiratory chain complexes were found to be normal at least in skeletal muscle. These biallelic loss-of-function variants of MFF were recognized as causing extremely elongated, interconnected mitochondria and peroxisomes, and loss of DRP1 recruitment to the fission nodes in cells isolated from the affected individuals (191).

\section{Conclusion}

Inherited optic nerve degeneration due to dysfunction of mitochondrial metabolism and predominantly respiratory chain defects has been identified in patients with Leber's hereditary optic neuropathy harboring mtDNA mutations, as well as individuals carrying mutations in novel genes, such as transmembrane protein 126A (TMEM126A), aconitase 2 $(A C O 2)$, reticulon 4-interacting protein 1 (RTN4IPl), chromosome 12 ORF 65 (C12orf65), NADH: ubiquinone oxidoreductase core subunit (S2NDUFS2), mitochondrial tRNA translation optimization 1 (MTO1), and deafness dystonia protein 1 (DDPl) (41). However, the pathogenic mechanism underlying RGC loss is much more complex and impairment of mitochondrial network dynamics due to genetic defects has also been shown to account, alone or in combination with bioenergetic crisis, for syndromic or isolated optic neuropathies.
Several inter-related molecular, tissue-specific factors seem to create a complex interacting network not fully understood yet which dictates mitochondrial function and thereby cellular and tissue integrity. This complexity may be responsible for genotype-phenotype disparity and this translates into phenotypic heterogeity, a hallmark for the need for early and correct diagnosis of these disorders. The application of more advanced techniques regarding CNS (MRI) and nerve fiber layer (OCT) imaging in recent years offers an accurate evaluation of CNS/optic nerve involvement, recognition of asymptomatic patients and subsequent expansion of the phenotypic spectrum. It is obvious that a comprehensive phenotypic profile combined with knowledge gained from detailed genotypic characterization, molecular studies on cells isolated from affected patients and transgenic animal disease models is the only promising approach in order to dissect the relative role of the involved molecules and elucidate the signal pathways underlying these monogenic, as well as complex, neurodegenerative disorders. To that end, generation of induced pluripotent stem cells by reprogramming fibroblasts isolated from affected individuals and their subsequent differentiation into various neural cell populations will expand further the knowledge regarding the susceptibility of particular cell types, such as RGCs, to specific genetic alterations.

Although treatment options concerning disorders of mitochondrial dynamics are currently limited, the future is open for the development of novel neuroprotective strategies and innovative gene-therapy approaches. Novel therapeutic strategies include genetic engineering to correct or silence particular gene mutations and pharmacological approaches targeting the structure of the affected protein (120). Finally, understanding the aspect of mitochondrial function and subsequent cellular process that is affected by a particular genetic defects might offer an alternative more global therapeutic option by enabling the development of efficient treatment targeting the process rather than the gene itself.

\section{References}

1 Friedman JR and Nunnari J: Mitochondrial form and function. Nature 505: 335-343, 2014.

2 Mishra P and Chan DC: Metabolic regulation of mitochondrial dynamics. J Cell Biol 212: 379-387, 2016.

3 Wai $\mathrm{T}$ and Langer T: Mitochondrial dynamics and metabolic regulation. Trends Endocrinol Metab 27: 105-117, 2016.

4 Burte F, Carelli V, Chinnery PF and Yu-Wai-Man P: Disturbed mitochondrial dynamics and neurodegenerative disorders. Nat Rev Neurol 11: 11-24, 2015.

5 Hoppins S: The regulation of mitochondrial dynamics. Curr Opin Cell Biol 29: 46-52, 2014.

6 Labbe K, Murley A and Nunnari J: Determinants and functions of mitochondrial behavior. Annu Rev Cell Dev Biol 30: 357-391, 2014. 
7 Toyama EQ, Herzig S, Courchet J, Lewis TL Jr., Loson OC, Hellberg K, Young NP, Chen H, Polleux F, Chan DC and Shaw RJ: Metabolism. AMP-activated protein kinase mediates mitochondrial fission in response to energy stress. Science 351: 275-281, 2016.

8 Schon EA and Przedborski S: Mitochondria: the next (neurode)generation. Neuron 70: 1033-1053, 2011.

9 Schon EA and Manfredi G: Neuronal degeneration and mitochondrial dysfunction. J Clin Invest 111: 303-312, 2003.

10 Haun F, Nakamura T and Lipton SA: Dysfunctional mitochondrial dynamics in the pathophysiology of neurodegenerative diseases. J Cell Death 6: 27-35, 2013.

11 Stuppia G, Rizzo F, Riboldi G, Del Bo R, Nizzardo M, Simone C, Comi GP, Bresolin N and Corti S: MFN2-related neuropathies: Clinical features, molecular pathogenesis and therapeutic perspectives. J Neurol Sci 356: 7-18, 2015.

12 Bagli E, Goussia A, Moschos MM, Agnantis N and Kitsos G: Natural compounds and neuroprotection: mechanisms of action and novel delivery systems. In Vivo 30: 535-547, 2016.

13 Legros F, Malka F, Frachon P, Lombes A and Rojo M: Organization and dynamics of human mitochondrial DNA. J Cell Sci 117: 2653-2662, 2004

14 Wilkens V, Kohl W and Busch K: Restricted diffusion of OXPHOS complexes in dynamic mitochondria delays their exchange between cristae and engenders a transitory mosaic distribution. J Cell Sci 126: 103-116, 2013.

15 Twig G, Hyde B and Shirihai OS: Mitochondrial fusion, fission and autophagy as a quality control axis: the bioenergetic view. Biochim Biophys Acta 1777: 1092-1097, 2008.

16 Ishihara $\mathrm{T}$, Kohno $\mathrm{H}$ and Ishihara $\mathrm{N}$ : Physiological roles of mitochondrial fission in cultured cells and mouse development. Ann N Y Acad Sci 1350: 77-81, 2015.

17 Ni HM, Williams JA and Ding WX: Mitochondrial dynamics and mitochondrial quality control. Redox Biol 4: 6-13, 2015.

18 Otera $\mathrm{H}$, Ishihara $\mathrm{N}$ and Mihara $\mathrm{K}$ : New insights into the function and regulation of mitochondrial fission. Biochim Biophys Acta 1833: 1256-1268, 2013.

19 Mitra K: Mitochondrial fission-fusion as an emerging key regulator of cell proliferation and differentiation. Bioessays 35 : 955-964, 2013.

20 Kasahara A and Scorrano L: Mitochondria: from cell death executioners to regulators of cell differentiation. Trends Cell Biol 24: 761-770, 2014.

21 Zorzano A, Liesa M, Sebastian D, Segales J and Palacin M: Mitochondrial fusion proteins: dual regulators of morphology and metabolism. Semin Cell Dev Biol 21: 566-574, 2010.

22 Olichon A, Guillou E, Delettre C, Landes T, Arnaune-Pelloquin L, Emorine LJ, Mils V, Daloyau M, Hamel C, Amati-Bonneau P, Bonneau D, Reynier $P$, Lenaers $G$ and Belenguer $P$ : Mitochondrial dynamics and disease, OPA1. Biochim Biophys Acta 1763: 500-509, 2006.

23 Smirnova E, Griparic L, Shurland DL and van der Bliek AM: Dynamin-related protein DRP1 is required for mitochondrial division in mammalian cells. Mol Biol Cell 12: 2245-2256, 2001.

24 Detmer SA and Chan DC: Functions and dysfunctions of mitochondrial dynamics. Nat Rev Mol Cell Biol 8: 870-879, 2007.

25 Cipolat S, Rudka T, Hartmann D, Costa V, Serneels L, Craessaerts K, Metzger K, Frezza C, Annaert W, D'Adamio L, Derks C, Dejaegere T, Pellegrini L, D'Hooge R, Scorrano L and De Strooper B: Mitochondrial rhomboid PARL regulates cytochrome c release during apoptosis via OPA1-dependent cristae remodeling. Cell 126: 163-175, 2006.

26 Cogliati S, Frezza C, Soriano ME, Varanita T, Quintana-Cabrera R, Corrado M, Cipolat S, Costa V, Casarin A, Gomes LC, Perales-Clemente E, Salviati L, Fernandez-Silva P, Enriquez JA and Scorrano L: Mitochondrial crista shape determines respiratory chain supercomplexes assembly and respiratory efficiency. Cell 155: 160-171, 2013.

27 Griparic L, van der Wel NN, Orozco IJ, Peters PJ and van der Bliek AM: Loss of the intermembrane space protein MGM1/ OPA1 induces swelling and localized constrictions along the lengths of mitochondria. J Biol Chem 279: 18792-18798, 2004.

28 Ishihara N, Fujita Y, Oka T and Mihara K: Regulation of mitochondrial morphology through proteolytic cleavage of OPA1. EMBO J 25: 2966-2977, 2006.

29 Martinelli P and Rugarli EI: Emerging roles of mitochondrial proteases in neurodegeneration. Biochim Biophys Acta 1797: $1-10,2010$.

30 Anand R, Wai T, Baker MJ, Kladt N, Schauss AC, Rugarli E and Langer T: The i-AAA protease YME1L and OMA1 cleave OPA1 to balance mitochondrial fusion and fission. J Cell Biol 204: 919-929, 2014.

31 Verhoeven K, Claeys KG, Zuchner S, Schroder JM, Weis J, Ceuterick C, Jordanova A, Nelis E, De Vriendt E, Van Hul M, Seeman P, Mazanec R, Saifi GM, Szigeti K, Mancias P, Butler IJ, Kochanski A, Ryniewicz B, De Bleecker J, Van den Bergh P, Verellen C, Van Coster R, Goemans N, Auer-Grumbach M, Robberecht W, Milic Rasic V, Nevo Y, Tournev I, Guergueltcheva V, Roelens F, Vieregge P, Vinci P, Moreno MT, Christen HJ, Shy ME, Lupski JR, Vance JM, De Jonghe P and Timmerman V: MFN2 mutation distribution and genotype/phenotype correlation in Charcot-Marie-Tooth type 2. Brain 129: 2093-2102, 2006.

32 Ferre M, Caignard A, Milea D, Leruez S, Cassereau J, Chevrollier A, Amati-Bonneau P, Verny C, Bonneau D, Procaccio V and Reynier P: Improved locus-specific database for $O P A 1$ mutations allows inclusion of advanced clinical data. Hum Mutat 36: 20-25, 2015.

33 Loson OC, Song Z, Chen H and Chan DC: Fis1, Mff, MiD49, and MiD51 mediate DRP1 recruitment in mitochondrial fission. Mol Biol Cell 24: 659-667, 2013.

34 Gandre-Babbe $\mathrm{S}$ and van der Bliek AM: The novel tailanchored membrane protein MFF controls mitochondrial and peroxisomal fission in mammalian cells. Mol Biol Cell 19: 2402-2412, 2008.

35 Chang $\mathrm{CR}$ and Blackstone $\mathrm{C}$ : Dynamic regulation of mitochondrial fission through modification of the dynaminrelated protein DRP1. Ann N Y Acad Sci 1201: 34-39, 2010.

36 Wilson TJ, Slupe AM and Strack S: Cell signaling and mitochondrial dynamics: Implications for neuronal function and neurodegenerative disease. Neurobiol Dis 51: 13-26, 2013.

37 Saita S, Ishihara T, Maeda M, Iemura S, Natsume T, Mihara $\mathrm{K}$ and Ishihara $\mathrm{N}$ : Distinct types of protease systems are involved in homeostasis regulation of mitochondrial morphology via balanced fusion and fission. Genes Cells 21: 408-424, 2016.

38 Herlan M, Vogel F, Bornhovd C, Neupert W and Reichert AS: Processing of MGM1 by the rhomboid-type protease PCP1 is required for maintenance of mitochondrial morphology and of mitochondrial DNA. J Biol Chem 278: 27781-27788, 2003. 
39 Yue W, Chen Z, Liu H, Yan C, Chen M, Feng D, Yan C, Wu H, Du L, Wang Y, Liu J, Huang X, Xia L, Liu L, Wang X, Jin H, Wang J, Song Z, Hao X and Chen Q: A small natural molecule promotes mitochondrial fusion through inhibition of the deubiquitinase USP30. Cell Res 24: 482-496, 2014.

40 Votruba M: Molecular genetic basis of primary inherited optic neuropathies. Eye 18: 1126-1132, 2004.

41 Yu-Wai-Man P, Votruba M, Burte F, La Morgia C, Barboni P and Carelli V: A neurodegenerative perspective on mitochondrial optic neuropathies. Acta Neuropathol 132: 789-806, 2016.

42 Delettre C, Griffoin JM, Kaplan J, Dollfus H, Lorenz B, Faivre L, Lenaers G, Belenguer P and Hamel CP: Mutation spectrum and splicing variants in the OPA1 gene. Hum Genet 109: 584$591,2001$.

43 Davies V and Votruba M: Focus on molecules: the OPA1 protein. Exp Eye Res 83: 1003-1004, 2006.

44 Olichon A, Landes T, Arnaune-Pelloquin L, Emorine LJ, Mils V, Guichet A, Delettre C, Hamel C, Amati-Bonneau P, Bonneau D, Reynier $\mathrm{P}$, Lenaers $\mathrm{G}$ and Belenguer P: Effects of OPAl mutations on mitochondrial morphology and apoptosis: relevance to ADOA pathogenesis. J Cell Physiol 211: 423-430, 2007.

45 Lenaers G, Reynier P, Elachouri G, Soukkarieh C, Olichon A, Belenguer P, Baricault L, Ducommun B, Hamel C and Delettre C: OPA1 functions in mitochondria and dysfunctions in optic nerve. Int J Biochem Cell Biol 41: 1866-1874, 2009.

46 Olichon A, Emorine LJ, Descoins E, Pelloquin L, Brichese L, Gas N, Guillou E, Delettre C, Valette A, Hamel CP, Ducommun $B$, Lenaers $G$ and Belenguer P: The human dynamin-related protein OPA1 is anchored to the mitochondrial inner membrane facing the inter-membrane space. FEBS Lett 523: 171-176, 2002.

47 Amati-Bonneau P, Milea D, Bonneau D, Chevrollier A, Ferre M, Guillet V, Gueguen N, Loiseau D, de Crescenzo MA, Verny C, Procaccio V, Lenaers G and Reynier P: OPA1-associated disorders: phenotypes and pathophysiology. Int J Biochem Cell Biol 41: 1855-1865, 2009.

48 Frezza C, Cipolat S, Martins de Brito O, Micaroni M, Beznoussenko GV, Rudka T, Bartoli D, Polishuck RS, Danial NN, De Strooper B and Scorrano L: OPA1 controls apoptotic cristae remodeling independently from mitochondrial fusion. Cell 126: 177-189, 2006

49 Ding C, Wu Z, Huang L, Wang Y, Xue J, Chen S, Deng Z, Wang L, Song Z and Chen S: Mitofilin and CHCHD6 physically interact with SAM50 to sustain cristae structure. Sci Rep 5: 16064, 2015.

50 Yamaguchi R, Lartigue L, Perkins G, Scott RT, Dixit A, Kushnareva Y, Kuwana T, Ellisman MH and Newmeyer DD: OPA1-mediated cristae opening is BAX/BAK and BH3 dependent, required for apoptosis, and independent of BAK oligomerization. Mol Cell 31: 557-569, 2008.

51 Griparic L, Kanazawa T and van der Bliek AM: Regulation of the mitochondrial dynamin-like protein OPA1 by proteolytic cleavage. J Cell Biol 178: 757-764, 2007.

52 Elachouri G, Vidoni S, Zanna C, Pattyn A, Boukhaddaoui H, Gaget K, Yu-Wai-Man P, Gasparre G, Sarzi E, Delettre C, Olichon A, Loiseau D, Reynier P, Chinnery PF, Rotig A, Carelli V, Hamel CP, Rugolo M and Lenaers G: OPA1 links human mitochondrial genome maintenance to mtDNA replication and distribution. Genome Res 21: 12-20, 2011.

53 Belenguer P and Pellegrini L: The dynamin GTPase OPA1: More than mitochondria? Biochim Biophys Acta 1833: 176-183, 2013.
54 Patten DA, Wong J, Khacho M, Soubannier V, Mailloux RJ, Pilon-Larose K, MacLaurin JG, Park DS, McBride HM, TrinkleMulcahy L, Harper ME, Germain M and Slack RS: OPA1dependent cristae modulation is essential for cellular adaptation to metabolic demand. EMBO J 33: 2676-2691, 2014.

55 Mishra P, Carelli V, Manfredi G and Chan DC: Proteolytic cleavage of OPA1 stimulates mitochondrial inner membrane fusion and couples fusion to oxidative phosphorylation. Cell Metab 19: 630-641, 2014.

56 Lenaers G, Hamel C, Delettre C, Amati-Bonneau P, Procaccio V, Bonneau D, Reynier P and Milea D: Dominant optic atrophy. Orphanet J Rare Dis 7: 46, 2012.

57 Leruez S, Amati-Bonneau P, Verny C, Reynier P, Procaccio V, Bonneau D and Milea D: Mitochondrial dysfunction affecting visual pathways. Rev Neurol 170: 344-354, 2014.

58 Yu-Wai-Man P, Griffiths PG, Gorman GS, Lourenco CM, Wright AF, Auer-Grumbach M, Toscano A, Musumeci O, Valentino ML, Caporali L, Lamperti C, Tallaksen CM, Duffey P, Miller J, Whittaker RG, Baker MR, Jackson MJ, Clarke MP, Dhillon B, Czermin B, Stewart JD, Hudson G, Reynier P, Bonneau D, Marques W Jr., Lenaers G, McFarland R, Taylor RW, Turnbull DM, Votruba M, Zeviani M, Carelli V, Bindoff LA, Horvath R, Amati-Bonneau P and Chinnery PF: Multi-system neurological disease is common in patients with OPA1 mutations. Brain 133: 771-786, 2010.

59 Newman NJ: Treatment of hereditary optic neuropathies. Nat Rev Neurol 8: 545-556, 2012.

60 Roubertie A, Leboucq N, Picot MC, Nogue E, Brunel H, Le Bars E, Manes G, Angebault Prouteau C, Blanchet C, Mondain M, Chevassus H, Amati-Bonneau P, Sarzi E, Pages M, Villain M, Meunier I, Lenaers G and Hamel CP: Neuroradiological findings expand the phenotype of OPA1-related mitochondrial dysfunction. J Neurol Sci 349: 154-160, 2015.

61 Chao de la Barca JM, Prunier-Mirebeau D, Amati-Bonneau P, Ferre M, Sarzi E, Bris C, Leruez S, Chevrollier A, DesquiretDumas V, Gueguen N, Verny C, Hamel C, Milea D, Procaccio V, Bonneau D, Lenaers G and Reynier P: OPA1-related disorders: Diversity of clinical expression, modes of inheritance and pathophysiology. Neurobiol Dis 90: 20-26, 2016.

62 Ferre M, Amati-Bonneau P, Tourmen Y, Malthiery Y and Reynier P: eOPA1: an online database for OPA1 mutations. Hum Mutat 25: 423-428, 2005.

63 Pesch UE, Leo-Kottler B, Mayer S, Jurklies B, Kellner U, Apfelstedt-Sylla E, Zrenner E, Alexander C and Wissinger B: OPA1 mutations in patients with autosomal dominant optic atrophy and evidence for semi-dominant inheritance. Hum Mol Genet 10: 1359-1368, 2001.

64 Wong ED, Wagner JA, Scott SV, Okreglak V, Holewinske TJ, Cassidy-Stone A and Nunnari J: The intramitochondrial dynaminrelated GTPase, MGM1P, is a component of a protein complex that mediates mitochondrial fusion. J Cell Biol 160: 303-311, 2003.

65 Marchbank NJ, Craig JE, Leek JP, Toohey M, Churchill AJ, Markham AF, Mackey DA, Toomes $\mathrm{C}$ and Inglehearn CF: Deletion of the OPAl gene in a dominant optic atrophy family: evidence that haploinsufficiency is the cause of disease. J Med Genet 39: e47, 2002.

66 Fuhrmann N, Alavi MV, Bitoun P, Woernle S, Auburger G, LeoKottler B, Yu-Wai-Man P, Chinnery P and Wissinger B: Genomic rearrangements in OPAl are frequent in patients with autosomal dominant optic atrophy. J Med Genet 46: 136-144, 2009. 
67 Schimpf S, Schaich S and Wissinger B: Activation of cryptic splice sites is a frequent splicing defect mechanism caused by mutations in exon and intron sequences of the OPAl gene. Hum Genet 118: 767-771, 2006.

68 Zanna C, Ghelli A, Porcelli AM, Karbowski M, Youle RJ, Schimpf S, Wissinger B, Pinti M, Cossarizza A, Vidoni S, Valentino ML, Rugolo $\mathrm{M}$ and Carelli V: OPAl mutations associated with dominant optic atrophy impair oxidative phosphorylation and mitochondrial fusion. Brain 131: 352-367, 2008.

69 Ferraris S, Clark S, Garelli E, Davidzon G, Moore SA, Kardon RH, Bienstock RJ, Longley MJ, Mancuso M, Gutierrez Rios P, Hirano M, Copeland WC and DiMauro S: Progressive external ophthalmoplegia and vision and hearing loss in a patient with mutations in POLG2 and OPA1. Arch Neurol 65: 125-131, 2008.

70 Hudson G, Amati-Bonneau P, Blakely EL, Stewart JD, He L, Schaefer AM, Griffiths PG, Ahlqvist K, Suomalainen A, Reynier P, McFarland R, Turnbull DM, Chinnery PF and Taylor RW: Mutation of OPAl causes dominant optic atrophy with external ophthalmoplegia, ataxia, deafness and multiple mitochondrial DNA deletions: a novel disorder of mtDNA maintenance. Brain 131: 329-337, 2008.

71 Yu-Wai-Man P, Griffiths PG and Chinnery PF: Mitochondrial optic neuropathies - disease mechanisms and therapeutic strategies. Prog Retin Eye Res 30: 81-114, 2011.

72 Barboni P, Savini G, Cascavilla ML, Caporali L, Milesi J, Borrelli E, La Morgia C, Valentino ML, Triolo G, Lembo A, Carta A, De Negri A, Sadun F, Rizzo G, Parisi V, Pierro L, Bianchi Marzoli S, Zeviani M, Sadun AA, Bandello F and Carelli $\mathrm{V}$ : Early macular retinal ganglion cell loss in dominant optic atrophy: genotype-phenotype correlation. Am J Ophthalmol 158: 628-636e623, 2014.

73 Puomila A, Huoponen K, Mantyjarvi M, Hamalainen P, Paananen R, Sankila EM, Savontaus ML, Somer M and Nikoskelainen E: Dominant optic atrophy: correlation between clinical and molecular genetic studies. Acta Ophthalmol Scand 83: 337-346, 2005

74 Amati-Bonneau P, Valentino ML, Reynier P, Gallardo ME, Bornstein B, Boissiere A, Campos Y, Rivera H, de la Aleja JG, Carroccia R, Iommarini L, Labauge P, Figarella-Branger D, Marcorelles P, Furby A, Beauvais K, Letournel F, Liguori R, La Morgia C, Montagna P, Liguori M, Zanna C, Rugolo M, Cossarizza A, Wissinger B, Verny C, Schwarzenbacher R, Martin MA, Arenas J, Ayuso C, Garesse R, Lenaers G, Bonneau $\mathrm{D}$ and Carelli V: OPA1 mutations induce mitochondrial DNA instability and optic atrophy 'plus' phenotypes. Brain 131: 338$351,2008$.

75 Chevrollier A, Guillet V, Loiseau D, Gueguen N, de Crescenzo MA, Verny C, Ferre M, Dollfus H, Odent S, Milea D, Goizet C, Amati-Bonneau P, Procaccio V, Bonneau D and Reynier P: Hereditary optic neuropathies share a common mitochondrial coupling defect. Ann Neurol 63: 794-798, 2008.

76 Yu-Wai-Man P, Shankar SP, Biousse V, Miller NR, Bean LJ, Coffee B, Hegde M and Newman NJ: Genetic screening for $O P A 1$ and $O P A 3$ mutations in patients with suspected inherited optic neuropathies. Ophthalmology 118: 558-563, 2011.

77 Pierron D, Ferre M, Rocher C, Chevrollier A, Murail P, Thoraval D, Amati-Bonneau P, Reynier P and Letellier T: OPAl-related dominant optic atrophy is not strongly influenced by mitochondrial DNA background. BMC Med Genet 10: 70, 2009.
78 Maresca A, la Morgia C, Caporali L, Valentino ML and Carelli V: The optic nerve: a "mito-window" on mitochondrial neurodegeneration. Mol Cell Neurosci 55: 62-76, 2013.

79 Mayorov VI, Lowrey AJ, Biousse V, Newman NJ, Cline SD and Brown MD: Mitochondrial oxidative phosphorylation in autosomal dominant optic atrophy. BMC Biochem 9: 22, 2008.

80 Langer T: AAA proteases: cellular machines for degrading membrane proteins. Trends Biochem Sci 25: 247-251, 2000.

81 Ehses S, Raschke I, Mancuso G, Bernacchia A, Geimer S, Tondera D, Martinou JC, Westermann B, Rugarli EI and Langer $\mathrm{T}$ : Regulation of OPA 1 processing and mitochondrial fusion by m-AAA protease isoenzymes and OMA1. J Cell Biol 187: 10231036, 2009.

82 Koppen M, Metodiev MD, Casari G, Rugarli EI and Langer T: Variable and tissue-specific subunit composition of mitochondrial m-AAA protease complexes linked to hereditary spastic paraplegia. Mol Cell Biol 27: 758-767, 2007.

83 Richter U, Lahtinen T, Marttinen P, Suomi F and Battersby BJ: Quality control of mitochondrial protein synthesis is required for membrane integrity and cell fitness. J Cell Biol 211: 373-389, 2015.

84 Nolden M, Ehses S, Koppen M, Bernacchia A, Rugarli EI and Langer T: The m-AAA protease defective in hereditary spastic paraplegia controls ribosome assembly in mitochondria. Cell 123: 277-289, 2005.

85 Tatsuta $\mathrm{T}$ and Langer $\mathrm{T}$ : Quality control of mitochondria: protection against neurodegeneration and ageing. EMBO J 27: 306-314, 2008.

86 Shanmughapriya S, Rajan S, Hoffman NE, Higgins AM, Tomar D, Nemani N, Hines KJ, Smith DJ, Eguchi A, Vallem S, Shaikh F, Cheung M, Leonard NJ, Stolakis RS, Wolfers MP, Ibetti J, Chuprun JK, Jog NR, Houser SR, Koch WJ, Elrod JW and Madesh M: SPG7 Is an essential and conserved component of the mitochondrial permeability transition pore. Mol Cell 60: 4762, 2015

87 Ferreirinha F, Quattrini A, Pirozzi M, Valsecchi V, Dina G, Broccoli V, Auricchio A, Piemonte F, Tozzi G, Gaeta L, Casari G, Ballabio A and Rugarli EI: Axonal degeneration in paraplegin-deficient mice is associated with abnormal mitochondria and impairment of axonal transport. J Clin Invest 113: 231-242, 2004.

88 De Michele G, De Fusco M, Cavalcanti F, Filla A, Marconi R, Volpe G, Monticelli A, Ballabio A, Casari G and Cocozza S: A new locus for autosomal recessive hereditary spastic paraplegia maps to chromosome 16q24.3. Am J Hum Genet 63: 135-139, 1998.

89 Klebe S, Depienne C, Gerber S, Challe G, Anheim M, Charles P, Fedirko E, Lejeune E, Cottineau J, Brusco A, Dollfus H, Chinnery PF, Mancini C, Ferrer X, Sole G, Destee A, Mayer JM, Fontaine B, de Seze J, Clanet M, Ollagnon E, Busson P, Cazeneuve C, Stevanin G, Kaplan J, Rozet JM, Brice A and Durr A: Spastic paraplegia gene 7 in patients with spasticity and/or optic neuropathy. Brain 135: 2980-2993, 2012.

90 Schule R and Schols L: Genetics of hereditary spastic paraplegias. Semin Neurol 31: 484-493, 2011.

91 Casari G, De Fusco M, Ciarmatori S, Zeviani M, Mora M, Fernandez P, De Michele G, Filla A, Cocozza S, Marconi R, Durr A, Fontaine B and Ballabio A: Spastic paraplegia and OXPHOS impairment caused by mutations in paraplegin, a nuclear-encoded mitochondrial metalloprotease. Cell 93: 973-983, 1998. 
92 McDermott CJ, Dayaratne RK, Tomkins J, Lusher ME, Lindsey JC, Johnson MA, Casari G, Turnbull DM, Bushby K and Shaw PJ: Paraplegin gene analysis in hereditary spastic paraparesis (HSP) pedigrees in northeast England. Neurology 56: 467-471, 2001.

93 Elleuch N, Depienne C, Benomar A, Hernandez AM, Ferrer X, Fontaine B, Grid D, Tallaksen CM, Zemmouri R, Stevanin G, Durr A and Brice A: Mutation analysis of the paraplegin gene $(S P G 7)$ in patients with hereditary spastic paraplegia. Neurology 66: 654-659, 2006.

94 Warnecke T, Duning T, Schwan A, Lohmann H, Epplen JT and Young P: A novel form of autosomal recessive hereditary spastic paraplegia caused by a new SPG7 mutation. Neurology 69: 368375, 2007.

95 Tzoulis C, Denora PS, Santorelli FM and Bindoff LA: Hereditary spastic paraplegia caused by the novel mutation 1047insC in the SPG7 gene. J Neurol 255: 1142-1144, 2008

96 Wilkinson PA, Crosby AH, Turner C, Bradley LJ, Ginsberg L, Wood NW, Schapira AH and Warner TT: A clinical, genetic and biochemical study of SPG7 mutations in hereditary spastic paraplegia. Brain 127: 973-980, 2004.

97 Brugman F, Scheffer H, Wokke JH, Nillesen WM, de Visser M, Aronica E, Veldink JH and van den Berg LH: Paraplegin mutations in sporadic adult-onset upper motor neuron syndromes. Neurology 71: 1500-1505, 2008.

98 Sanchez-Ferrero E, Coto E, Beetz C, Gamez J, Corao AI, Diaz M, Esteban J, del Castillo E, Moris G, Infante J, Menendez M, Pascual-Pascual SI, Lopez de Munain A, Garcia-Barcina MJ, Alvarez V and Genetics of Spastic Paraplegia Study Group: SPG7 mutational screening in spastic paraplegia patients supports a dominant effect for some mutations and a pathogenic role for p.A510V. Clin Genet 83: 257-262, 2013.

99 Bonn F, Pantakani K, Shoukier M, Langer T and Mannan AU: Functional evaluation of paraplegin mutations by a yeast complementation assay. Hum Mutat 31: 617-621, 2010.

100 Di Bella D, Lazzaro F, Brusco A, Plumari M, Battaglia G, Pastore A, Finardi A, Cagnoli C, Tempia F, Frontali M, Veneziano L, Sacco T, Boda E, Brussino A, Bonn F, Castellotti B, Baratta S, Mariotti C, Gellera C, Fracasso V, Magri S, Langer T, Plevani P, Di Donato S, Muzi-Falconi M and Taroni F: Mutations in the mitochondrial protease gene AFG3L2 cause dominant hereditary ataxia SCA28. Nat Genet 42: 313-321, 2010.

101 Edener U, Wollner J, Hehr U, Kohl Z, Schilling S, Kreuz F, Bauer P, Bernard V, Gillessen-Kaesbach G and Zuhlke C: Early onset and slow progression of SCA28, a rare dominant ataxia in a large four-generation family with a novel AFG3L2 mutation. Eur J Hum Genet 18: 965-968, 2010.

102 Pierson TM, Adams D, Bonn F, Martinelli P, Cherukuri PF, Teer JK, Hansen NF, Cruz P, Mullikin For The NISC Comparative Sequencing Program JC, Blakesley RW, Golas G, Kwan J, Sandler A, Fuentes Fajardo K, Markello T, Tifft C, Blackstone C, Rugarli EI, Langer T, Gahl WA and Toro C: Whole-exome sequencing identifies homozygous $A F G 3 L 2$ mutations in a spastic ataxia-neuropathy syndrome linked to mitochondrial mAAA proteases. PLoS Genet 7: e1002325, 2011.

103 Charif M, Roubertie A, Salime S, Mamouni S, Goizet C, Hamel $\mathrm{CP}$ and Lenaers G: A novel mutation of $A F G 3 L 2$ might cause dominant optic atrophy in patients with mild intellectual disability. Front Genet 6: 311, 2015.
104 Leonhard K, Herrmann JM, Stuart RA, Mannhaupt G, Neupert $\mathrm{W}$ and Langer T: AAA proteases with catalytic sites on opposite membrane surfaces comprise a proteolytic system for the ATPdependent degradation of inner membrane proteins in mitochondria. EMBO J 15: 4218-4229, 1996.

105 Shah ZH, Hakkaart GA, Arku B, de Jong L, van der Spek H, Grivell LA and Jacobs HT: The human homologue of the yeast mitochondrial AAA metalloprotease YME1P complements a yeast YME1 disruptant. FEBS Lett 478: 267-270, 2000.

106 Weber ER, Hanekamp T and Thorsness PE: Biochemical and functional analysis of the yme1 gene product, an ATP and zincdependent mitochondrial protease from $S$. cerevisiae. Mol Biol Cell 7: 307-317, 1996.

107 Rainey RN, Glavin JD, Chen HW, French SW, Teitell MA and Koehler CM: A new function in translocation for the mitochondrial i-AAA protease YME1: import of polynucleotide phosphorylase into the intermembrane space. Mol Cell Biol 26: 8488-8497, 2006.

108 Van Dyck L and Langer T: ATP-dependent proteases controlling mitochondrial function in the yeast Saccharomyces cerevisiae. Cell Mol Life Sci 56: 825-842, 1999.

109 Potting C, Tatsuta T, Konig T, Haag M, Wai T, Aaltonen MJ and Langer T: TRIAP1/PRELI complexes prevent apoptosis by mediating intramitochondrial transport of phosphatidic acid. Cell Metab 18: 287-295, 2013.

110 Baker MJ, Lampe PA, Stojanovski D, Korwitz A, Anand R, Tatsuta $\mathrm{T}$ and Langer T: Stress-induced OMA1 activation and autocatalytic turnover regulate OPA1-dependent mitochondrial dynamics. EMBO J 33: 578-593, 2014.

111 Rainbolt TK, Lebeau J, Puchades C and Wiseman RL: Reciprocal Degradation of YME1L and OMA1 adapts mitochondrial proteolytic activity during stress. Cell Rep 14: 2041-2049, 2016.

112 van der Bliek AM and Koehler CM: A mitochondrial rhomboid protease. Dev Cell 4: 769-770, 2003.

113 Wai T, Garcia-Prieto J, Baker MJ, Merkwirth C, Benit P, Rustin P, Ruperez FJ, Barbas C, Ibanez B and Langer T: Imbalanced OPA1 processing and mitochondrial fragmentation cause heart failure in mice. Science 350: aad0116, 2015.

114 Ruan Y, Li H, Zhang K, Jian F, Tang J and Song Z: Loss of YME1L perturbates mitochondrial dynamics. Cell Death Dis 4: e896, 2013.

115 Stiburek L, Cesnekova J, Kostkova O, Fornuskova D, Vinsova $\mathrm{K}$, Wenchich L, Houstek J and Zeman J: YME1L controls the accumulation of respiratory chain subunits and is required for apoptotic resistance, crista morphogenesis, and cell proliferation. Mol Biol Cell 23: 1010-1023, 2012.

116 Hartmann B, Wai T, Hu H, MacVicar T, Musante L, FischerZirnsak B, Stenzel W, Graf R, van den Heuvel L, Ropers HH, Wienker TF, Hubner C, Langer T and Kaindl AM: Homozygous YME1L1 mutation causes mitochondriopathy with optic atrophy and mitochondrial network fragmentation. Elife 5: e16078, 2016.

117 Rojo M, Legros F, Chateau D and Lombes A: Membrane topology and mitochondrial targeting of mitofusins, ubiquitous mammalian homologs of the transmembrane GTPase FZO. J Cell Sci 115: 1663-1674, 2002.

118 Kawalec M, Zablocka B, Kabzinska D, Neska J and Beresewicz M: Mitofusin 2 expression dominates over mitofusin 1 exclusively in mouse dorsal root ganglia - a possible explanation for peripheral nervous system involvement in Charcot-MarieTooth 2A. Folia Neuropathol 52: 436-442, 2014. 
119 Santel A and Fuller MT: Control of mitochondrial morphology by a human mitofusin. J Cell Sci 114: 867-874, 2001.

120 Franco A, Kitsis RN, Fleischer JA, Gavathiotis E, Kornfeld OS, Gong G, Biris N, Benz A, Qvit N, Donnelly SK, Chen Y, Mennerick S, Hodgson L, Mochly-Rosen D and Dorn GW, II: Correcting mitochondrial fusion by manipulating mitofusin conformations. Nature 540: 74-79, 2016.

121 Praefcke GJ and McMahon HT: The dynamin superfamily: Universal membrane tubulation and fission molecules? Nat Rev Mol Cell Biol 5: 133-147, 2004.

122 Huang P, Galloway CA and Yoon Y: Control of mitochondrial morphology through differential interactions of mitochondrial fusion and fission proteins. PLoS One 6: e20655, 2011.

123 van Vliet AR, Verfaillie T and Agostinis P: New functions of mitochondria associated membranes in cellular signaling. Biochim Biophys Acta 1843: 2253-2262, 2014.

124 Chan DC: Dissecting mitochondrial fusion. Dev Cell 11: 592594, 2006.

125 Cartoni R, Leger B, Hock MB, Praz M, Crettenand A, Pich S, Ziltener JL, Luthi F, Deriaz O, Zorzano A, Gobelet C, Kralli A and Russell AP: Mitofusins 1/2 and ERRalpha expression are increased in human skeletal muscle after physical exercise. J Physiol 567: 349-358, 2005.

126 Pich S, Bach D, Briones P, Liesa M, Camps M, Testar X, Palacin $\mathrm{M}$ and Zorzano A: The Charcot-Marie-Tooth type 2A gene product, MFN2, up-regulates fuel oxidation through expression of OXPHOS system. Hum Mol Genet 14: 1405-1415, 2005.

127 de Brito OM and Scorrano L: Mitofusin 2 tethers endoplasmic reticulum to mitochondria. Nature 456: 605-610, 2008.

128 Debattisti V, Pendin D, Ziviani E, Daga A and Scorrano L: Reduction of endoplasmic reticulum stress attenuates the defects caused by Drosophila mitofusin depletion. J Cell Biol 204: 303312, 2014.

129 Sebastian D, Hernandez-Alvarez MI, Segales J, Sorianello E, Munoz JP, Sala D, Waget A, Liesa M, Paz JC, Gopalacharyulu P, Oresic M, Pich S, Burcelin R, Palacin M and Zorzano A: Mitofusin 2 (MFN2) links mitochondrial and endoplasmic reticulum function with insulin signaling and is essential for normal glucose homeostasis. Proc Natl Acad Sci USA 109: 5523 $5528,2012$.

130 Chapman AL, Bennett EJ, Ramesh TM, De Vos KJ and Grierson AJ: Axonal transport defects in a mitofusin 2 loss of function model of charcot-Marie-Tooth disease in zebrafish. PLoS One 8 : e67276, 2013.

131 Misko AL, Sasaki Y, Tuck E, Milbrandt J and Baloh RH: Mitofusin2 mutations disrupt axonal mitochondrial positioning and promote axon degeneration. J Neurosci 32: 4145-4155, 2012.

132 Zuchner S, Mersiyanova IV, Muglia M, Bissar-Tadmouri N, Rochelle J, Dadali EL, Zappia M, Nelis E, Patitucci A, Senderek J, Parman Y, Evgrafov O, Jonghe PD, Takahashi Y, Tsuji S, Pericak-Vance MA, Quattrone A, Battaloglu E, Polyakov AV, Timmerman V, Schroder JM and Vance JM: Mutations in the mitochondrial GTPase mitofusin 2 cause Charcot-Marie-Tooth neuropathy type 2A. Nat Genet 36: 449-451, 2004.

133 Chalmers RM, Bird AC and Harding AE: Autosomal dominant optic atrophy with asymptomatic peripheral neuropathy. J Neurol Neurosurg Psychiatry 60: 195-196, 1996.

134 Leonardi L, Marcotulli C, Storti E, Tessa A, Serrao M, Parisi V, Santorelli FM, Pierelli F and Casali C: Acute optic neuropathy associated with a novel MFN2 mutation. J Neurol 262: 1678$1680,2015$.

135 Chung KW, Kim SB, Park KD, Choi KG, Lee JH, Eun HW, Suh JS, Hwang JH, Kim WK, Seo BC, Kim SH, Son IH, Kim SM, Sunwoo IN and Choi BO: Early onset severe and late-onset mild Charcot-Marie-Tooth disease with mitofusin 2 (MFN2) mutations. Brain 129: 2103-2118, 2006.

136 Lawson VH, Graham BV and Flanigan KM: Clinical and electrophysiologic features of CMT2A with mutations in the mitofusin 2 gene. Neurology 65: 197-204, 2005.

137 Bombelli F, Stojkovic T, Dubourg O, Echaniz-Laguna A, Tardieu S, Larcher K, Amati-Bonneau P, Latour P, Vignal O, Cazeneuve C, Brice A and Leguern E: Charcot-Marie-Tooth disease type 2A: from typical to rare phenotypic and genotypic features. JAMA Neurol 71: 1036-1042, 2014.

138 Feely SM, Laura M, Siskind CE, Sottile S, Davis M, Gibbons VS, Reilly MM and Shy ME: MFN2 mutations cause severe phenotypes in most patients with CMT2A. Neurology 76: 16901696, 2011.

139 Braathen GJ, Sand JC, Lobato A, Hoyer H and Russell MB: MFN2 point mutations occur in $3.4 \%$ of Charcot-Marie-Tooth families. An investigation of 232 Norwegian CMT families. BMC Med Genet 11: 48, 2010.

140 Rouzier C, Bannwarth S, Chaussenot A, Chevrollier A, Verschueren A, Bonello-Palot N, Fragaki K, Cano A, Pouget J, Pellissier JF, Procaccio V, Chabrol B and Paquis-Flucklinger V: The MFN2 gene is responsible for mitochondrial DNA instability and optic atrophy 'plus' phenotype. Brain 135: 23-34, 2012.

141 Klein CJ, Kimmel GW, Pittock SJ, Engelstad JE, Cunningham JM, Wu Y and Dyck PJ: Large kindred evaluation of mitofusin 2 novel mutation, extremes of neurologic presentations, and preserved nerve mitochondria. Arch Neurol 68: 1295-1302, 2011.

142 Cartoni R and Martinou JC: Role of mitofusin 2 mutations in the physiopathology of Charcot-Marie-Tooth disease type 2A. Exp Neurol 218: 268-273, 2009.

143 DiVincenzo C, Elzinga CD, Medeiros AC, Karbassi I, Jones JR, Evans MC, Braastad CD, Bishop CM, Jaremko M, Wang Z, Liaquat K, Hoffman CA, York MD, Batish SD, Lupski JR and Higgins JJ: The allelic spectrum of Charcot-Marie-Tooth disease in over 17,000 individuals with neuropathy. Mol Genet Genomic Med 2: 522-529, 2014.

144 Nicholson GA, Magdelaine C, Zhu D, Grew S, Ryan MM, Sturtz F, Vallat JM and Ouvrier RA: Severe early-onset axonal neuropathy with homozygous and compound heterozygous MFN2 mutations. Neurology 70: 1678-1681, 2008.

145 Calvo J, Funalot B, Ouvrier RA, Lazaro L, Toutain A, De Mas P, Bouche P, Gilbert-Dussardier B, Arne-Bes MC, Carriere JP, Journel H, Minot-Myhie MC, Guillou C, Ghorab K, Magy L, Sturtz F, Vallat JM and Magdelaine C: Genotype-phenotype correlations in Charcot-Marie-Tooth disease type 2 caused by mitofusin 2 mutations. Arch Neurol 66: 1511-1516, 2009.

146 Huizing M, Dorward H, Ly L, Klootwijk E, Kleta R, Skovby F, Pei W, Feldman B, Gahl WA and Anikster Y: OPA3, mutated in 3methylglutaconic aciduria type III, encodes two transcripts targeted primarily to mitochondria. Mol Genet Metab 100: 149-154, 2010.

147 Sergouniotis PI, Perveen R, Thiselton DL, Giannopoulos K, Sarros M, Davies JR, Biswas S, Ansons AM, Ashworth JL, Lloyd IC, Black GC and Votruba M: Clinical and molecular genetic findings in autosomal dominant OPA3-related optic neuropathy. Neurogenetics 16: 69-75, 2015. 
148 Yahalom G, Anikster Y, Huna-Baron R, Hoffmann C, Blumkin L, Lev D, Tsabari R, Nitsan Z, Lerman SF, Ben-Zeev B, PodeShakked B, Sofer S, Schweiger A, Lerman-Sagie T and HassinBaer S: Costeff syndrome: clinical features and natural history. J Neurol 261: 2275-2282, 2014.

149 Anikster Y, Kleta R, Shaag A, Gahl WA and Elpeleg O: Type III 3-methylglutaconic aciduria (optic atrophy plus syndrome, or Costeff optic atrophy syndrome): identification of the $O P A 3$ gene and its founder mutation in Iraqi Jews. Am J Hum Genet 69: 1218-1224, 2001.

150 Sofer S, Schweiger A, Blumkin L, Yahalom G, Anikster Y, Lev $\mathrm{D}$, Ben-Zeev B, Lerman-Sagie $\mathrm{T}$ and Hassin-Baer S: The neuropsychological profile of patients with 3-methylglutaconic aciduria type III, Costeff syndrome. Am J Med Genet B Neuropsychiatr Genet 168B: 197-203, 2015.

151 Pei W, Kratz LE, Bernardini I, Sood R, Yokogawa T, Dorward H, Ciccone C, Kelley RI, Anikster Y, Burgess HA, Huizing M and Feldman B: A model of Costeff Syndrome reveals metabolic and protective functions of mitochondrial OPA3. Development 137: 2587-2596, 2010.

152 Wortmann SB, Duran M, Anikster Y, Barth PG, Sperl W, Zschocke J, Morava $\mathrm{E}$ and Wevers RA: Inborn errors of metabolism with 3-methylglutaconic aciduria as discriminative feature: proper classification and nomenclature. J Inherit Metab Dis 36: 923-928, 2013.

153 Grau T, Burbulla LF, Engl G, Delettre C, Delprat B, Oexle K, Leo-Kottler B, Roscioli T, Kruger R, Rapaport D, Wissinger B and Schimpf-Linzenbold S: A novel heterozygous OPA3 mutation located in the mitochondrial target sequence results in altered steady-state levels and fragmented mitochondrial network. J Med Genet 50: 848-858, 2013.

154 Bourne SC, Townsend KN, Shyr C, Matthews A, Lear SA, Attariwala R, Lehman A, Wasserman WW, van Karnebeek C, Sinclair G, Vallance H and Gibson WT: Optic atrophy, cataracts, lipodystrophy/lipoatrophy, and peripheral neuropathy caused by a de novo OPA3 mutation. Cold Spring Harb Mol Case Stud 3: a001156, 2017.

155 Da Cruz S, Xenarios I, Langridge J, Vilbois F, Parone PA and Martinou JC: Proteomic analysis of the mouse liver mitochondrial inner membrane. J Biol Chem 278: 4156641571, 2003

156 Ryu SW, Jeong HJ, Choi M, Karbowski M and Choi C: Optic atrophy 3 as a protein of the mitochondrial outer membrane induces mitochondrial fragmentation. Cell Mol Life Sci 67: 2839-2850, 2010.

157 Ho G, Walter JH and Christodoulou J: Costeff optic atrophy syndrome: new clinical case and novel molecular findings. J Inherit Metab Dis 31(Suppl 2): S419-423, 2008.

158 Reynier P, Amati-Bonneau P, Verny C, Olichon A, Simard G, Guichet A, Bonnemains C, Malecaze F, Malinge MC, Pelletier JB, Calvas P, Dollfus H, Belenguer P, Malthiery Y, Lenaers G and Bonneau D: OPA3 gene mutations responsible for autosomal dominant optic atrophy and cataract. J Med Genet 41: e110, 2004.

159 Palmieri F: The mitochondrial transporter family SLC25: identification, properties and physiopathology. Mol Aspects Med 34: 465-484, 2013.

160 Sesaki H and Jensen RE: UGO1 encodes an outer membrane protein required for mitochondrial fusion. J Cell Biol 152: 11231134,2001
161 Coonrod EM, Karren MA and Shaw JM: Ugo1p is a multipass transmembrane protein with a single carrier domain required for mitochondrial fusion. Traffic 8: 500-511, 2007.

162 Hoppins S, Horner J, Song C, McCaffery JM and Nunnari J: Mitochondrial outer and inner membrane fusion requires a modified carrier protein. J Cell Biol 184: 569-581, 2009.

163 Anton F, Fres JM, Schauss A, Pinson B, Praefcke GJ, Langer T and Escobar-Henriques M: UGO1 and MDM30 act sequentially during FZO1-mediated mitochondrial outer membrane fusion. J Cell Sci 124: 1126-1135, 2011

164 Abrams AJ, Hufnagel RB, Rebelo A, Zanna C, Patel N, Gonzalez MA, Campeanu IJ, Griffin LB, Groenewald S, Strickland AV, Tao F, Speziani F, Abreu L, Schule R, Caporali L, La Morgia C, Maresca A, Liguori R, Lodi R, Ahmed ZM, Sund KL, Wang X, Krueger LA, Peng Y, Prada CE, Prows CA, Schorry EK, Antonellis A, Zimmerman HH, Abdul-Rahman OA, Yang Y, Downes SM, Prince J, Fontanesi F, Barrientos A, Nemeth AH, Carelli V, Huang T, Zuchner S and Dallman JE: Mutations in SLC25A46, encoding a UGO1-like protein, cause an optic atrophy spectrum disorder. Nat Genet 47: 926-932, 2015.

165 Sesaki H and Jensen RE: UGO1P Links the FZO1P and MGM1P GTPases for mitochondrial fusion. J Biol Chem 279: 2829828303, 2004

166 Steffen J, Vashisht AA, Wan J, Jen JC, Claypool SM, Wohlschlegel JA and Koehler CM: Rapid degradation of mutant SLC25A46 by the ubiquitin-proteasome system results in MFN1/2-mediated hyperfusion of mitochondria. Mol Biol Cell 28: 600-612, 2017.

167 Harner M, Korner C, Walther D, Mokranjac D, Kaesmacher J, Welsch U, Griffith J, Mann M, Reggiori F and Neupert W: The mitochondrial contact site complex, a determinant of mitochondrial architecture. EMBO J 30: 4356-4370, 2011.

168 Hoppins S, Collins SR, Cassidy-Stone A, Hummel E, Devay RM, Lackner LL, Westermann B, Schuldiner M, Weissman JS and Nunnari J: A mitochondrial-focused genetic interaction map reveals a scaffold-like complex required for inner membrane organization in mitochondria. J Cell Biol 195: 323-340, 2011.

169 van der Laan M, Bohnert M, Wiedemann N and Pfanner N: Role of MINOS in mitochondrial membrane architecture and biogenesis. Trends Cell Biol 22: 185-192, 2012.

170 Guarani V, McNeill EM, Paulo JA, Huttlin EL, Frohlich F, Gygi SP, Van Vactor D and Harper JW: QIL1 is a novel mitochondrial protein required for MICOS complex stability and cristae morphology. Elife 4: e06265, 2015.

171 Pfanner N, van der Laan M, Amati P, Capaldi RA, Caudy AA, Chacinska A, Darshi M, Deckers M, Hoppins S, Icho T, Jakobs S, Ji J, Kozjak-Pavlovic V, Meisinger C, Odgren PR, Park SK, Rehling P, Reichert AS, Sheikh MS, Taylor SS, Tsuchida N, van der Bliek AM, van der Klei IJ, Weissman JS, Westermann B, Zha J, Neupert W and Nunnari J: Uniform nomenclature for the mitochondrial contact site and cristae organizing system. J Cell Biol 204: 1083-1086, 2014.

172 Wan J, Steffen J, Yourshaw M, Mamsa H, Andersen E, RudnikSchoneborn S, Pope K, Howell KB, McLean CA, Kornberg AJ, Joseph J, Lockhart PJ, Zerres K, Ryan MM, Nelson SF, Koehler CM and Jen JC: Loss of function of SLC25A46 causes lethal congenital pontocerebellar hypoplasia. Brain 139(11): 2877-2890, 2016.

173 Lahiri S, Chao JT, Tavassoli S, Wong AK, Choudhary V, Young BP, Loewen CJ and Prinz WA: A conserved endoplasmic reticulum membrane protein complex (EMC) facilitates phospholipid transfer from the ER to mitochondria. PLoS Biol 12: e1001969, 2014. 
174 Janer A, Prudent J, Paupe V, Fahiminiya S, Majewski J, Sgarioto N, Des Rosiers C, Forest A, Lin ZY, Gingras AC, Mitchell G, McBride HM and Shoubridge EA: SLC25A46 is required for mitochondrial lipid homeostasis and cristae maintenance and is responsible for Leigh syndrome. EMBO Mol Med 8: 1019-1038, 2016.

175 Harel T, Yoon WH, Garone C, Gu S, Coban-Akdemir Z, Eldomery MK, Posey JE, Jhangiani SN, Rosenfeld JA, Cho MT, Fox S, Withers M, Brooks SM, Chiang T, Duraine L, Erdin S, Yuan B, Shao Y, Moussallem E, Lamperti C, Donati MA, Smith JD, McLaughlin HM, Eng CM, Walkiewicz M, Xia F, Pippucci T, Magini P, Seri M, Zeviani M, Hirano M, Hunter JV, Srour M, Zanigni S, Lewis RA, Muzny DM, Lotze TE, Boerwinkle E, Baylor-Hopkins Center for Mendelian G, University of Washington Center for Mendelian G, Gibbs RA, Hickey SE, Graham BH, Yang Y, Buhas D, Martin DM, Potocki L, Graziano $\mathrm{C}$, Bellen HJ and Lupski JR: Recurrent de novo and biallelic variation of $A T A D 3 A$, encoding a mitochondrial membrane protein, results in distinct neurological syndromes. Am J Hum Genet 99: 831-845, 2016.

176 Li S, Lamarche F, Charton R, Delphin C, Gires O, Hubstenberger A, Schlattner U and Rousseau D: Expression analysis of ATAD3 isoforms in rodent and human cell lines and tissues. Gene 535: 60-69, 2014.

177 Goller T, Seibold UK, Kremmer E, Voos W and Kolanus W: ATAD3 function is essential for early post-implantation development in the mouse. PLoS One 8: e54799, 2013.

178 Gilquin B, Taillebourg E, Cherradi N, Hubstenberger A, Gay O, Merle N, Assard N, Fauvarque MO, Tomohiro S, Kuge O and Baudier J: The AAA+ ATPase ATAD3A controls mitochondrial dynamics at the interface of the inner and outer membranes. Mol Cell Biol 30: 1984-1996, 2010.

179 Issop L, Fan J, Lee S, Rone MB, Basu K, Mui J and Papadopoulos V: Mitochondria-associated membrane formation in hormone-stimulated Leydig cell steroidogenesis: role of ATAD3. Endocrinology 156: 334-345, 2015.

180 Rone MB, Midzak AS, Issop L, Rammouz G, Jagannathan S, Fan J, Ye X, Blonder J, Veenstra $\mathrm{T}$ and Papadopoulos V: Identification of a dynamic mitochondrial protein complex driving cholesterol import, trafficking, and metabolism to steroid hormones. Mol Endocrinol 26: 1868-1882, 2012.

$181 \mathrm{He}$ J, Cooper HM, Reyes A, Di Re M, Sembongi H, Litwin TR, Gao J, Neuman KC, Fearnley IM, Spinazzola A, Walker JE and Holt IJ: Mitochondrial nucleoid interacting proteins support mitochondrial protein synthesis. Nucleic Acids Res 40: 61096121,2012
182 Teng Y, Ren X, Li H, Shull A, Kim J and Cowell JK: Mitochondrial ATAD3A combines with GRP78 to regulate the WASF3 metastasis-promoting protein. Oncogene 35: 333-343, 2016.

183 Mears JA, Lackner LL, Fang S, Ingerman E, Nunnari J and Hinshaw JE: Conformational changes in DNM1 support a contractile mechanism for mitochondrial fission. Nat Struct Mol Biol 18: 20-26, 2011.

184 Liu R and Chan DC: The mitochondrial fission receptor Mff selectively recruits oligomerized Drp1. Mol Biol Cell 26: 44664477, 2015.

185 Chang CR, Manlandro CM, Arnoult D, Stadler J, Posey AE, Hill $\mathrm{RB}$ and Blackstone $\mathrm{C}$ : A lethal de novo mutation in the middle domain of the dynamin-related GTPase Drp1 impairs higher order assembly and mitochondrial division. J Biol Chem 285: 32494-32503, 2010.

186 Wakabayashi J, Zhang Z, Wakabayashi N, Tamura Y, Fukaya M, Kensler TW, Iijima $M$ and Sesaki $H$ : The dynamin-related GTPase Drp1 is required for embryonic and brain development in mice. J Cell Biol 186: 805-816, 2009.

187 Waterham HR, Koster J, van Roermund CW, Mooyer PA, Wanders RJ and Leonard JV: A lethal defect of mitochondrial and peroxisomal fission. N Engl J Med 356: 1736-1741, 2007.

188 Schrader M, Costello J, Godinho LF and Islinger M: Peroxisomemitochondria interplay and disease. J Inherit Metab Dis 38: 681702,2015

189 Otera H, Wang C, Cleland MM, Setoguchi K, Yokota S, Youle $\mathrm{RJ}$ and Mihara K: Mff is an essential factor for mitochondrial recruitment of DRP1 during mitochondrial fission in mammalian cells. J Cell Biol 191: 1141-1158, 2010.

190 Shamseldin HE, Alshammari M, Al-Sheddi T, Salih MA, Alkhalidi H, Kentab A, Repetto GM, Hashem M and Alkuraya FS: Genomic analysis of mitochondrial diseases in a consanguineous population reveals novel candidate disease genes. J Med Genet 49: 234-241, 2012.

191 Koch J, Feichtinger RG, Freisinger P, Pies M, Schrodl F, Iuso A, Sperl W, Mayr JA, Prokisch H and Haack TB: Disturbed mitochondrial and peroxisomal dynamics due to loss of MFF causes Leigh-like encephalopathy, optic atrophy and peripheral neuropathy. J Med Genet 53: 270-278, 2016.

Received March 28, 2017

Revised April 14, 2017

Accepted April 19, 2017 